\title{
Implementasi Sistem Pakar Menggunakan Metode Certainty Factor Untuk Mendiagnosa Dini Corona Virus Desease (COVID-19)
}

\author{
Muhamad Fajar Suryana*, Fauziah, Ratih Titi Komala Sari \\ Fakultas Teknologi Komunikasi dan Informatika, Sistem Informasi, Universitas Nasional, Jakarta, Indonesia \\ Email: 1," fjrsurya30@ gmail.com, ${ }^{2}$ fauziah@civitas.unas.ac.id, ${ }^{3}$ ratih@ @ivitas.unas.ac.id \\ Email Penulis Korespondensi: fjrsurya30@gmail.com
}

\begin{abstract}
Abstrak-Manusia sedang dihadapkan bencana non alam yang mengancam seluruh populasi manusia di Bumi. Bencana non alam itu bernama Corona Virus Desease (COVID-19), yaitu keluarga besar virus yang dapat menyerang manusia dan hewan yang saat ini menjadi pandemic global. Pada manusia biasanya menyebabkan penyakit infeksi saluran pernafasan, mulai dari flu biasa hingga penyakit serius seperti MERS dan SARS. COVID-19 sendiri merupakan coronavirus jenis baru yang ditemukan pada manusia dan di daerah Wuhan, Provinsi Hubei, China pada tahun 2019. Untuk membantu para tenaga medis dalam mendeteksi dini gejala-gejala yang dialami oleh pasien dan memudahkan pencatatan administrasi oleh pihak rumah sakit, maka salah satunya dibuat system pakar yang dapat mendeteksi dini COVID-19 ini dengan metode Certainty Factor (CF). sistem pakar ini meniru gejala-gejala yang mirip yang dialami oleh pasien COVID-19 dan akan dikelompokan menjadi beberapa status pasien. Pasien yang mengalami gejala serius akan dikelompokan menjadi Pasien Dalam Pengawasan (PDP) dan pasien yang dianggap memiliki gejala lebih ringan akan dikelompokan kedalam status Orang Dalam Pengawasan (ODP) sedangkan yang mengalami gejala yang diluar dari gejala utama akan dikelompokan menjadi status Non Suspect (NON). Dari 152 data pasien yang diinput pada penelitian ini mendapatkan hasil 114 ODP dengan rata-rata nilai CF 91,38\% , 36 PDP deangan rata-rata nilai CF 98,25\% dan 2 NON dengan rata-rata nilai CF $40 \%$. CF dengan percobaan perhitungan sistem yaitu data yang mewakili pasien mendapatkan nilai CF 0.998848 atau $99.88 \%$ menjadi PDP. Sistem pakar ini dapat digunakan pengambilan keputusan yang dapat membantu tenaga medis melakukan tindakan dan pengadministrasian dengan lebih baik sebelum dilakukan tes secara menyeluruh di laboratorium untuk memastikan pasien positif atau negatif COVID-19.
\end{abstract}

Kata Kunci: CF, COVID-19, ODP, PDP, NON, Pasien

\begin{abstract}
Humans are facing a non-natural disaster that threatens the entire human population on Earth. Non-natural disaster is called Corona Virus Desease (COVID-19), which is a large family of viruses that can attack humans and animals that are currently a global pandemic. Humans usually cause respiratory infections, ranging from the common cold to serious illnesses such as MERS and SARS. COVID-19 itself is a new type of coronavirus found in humans and in the Wuhan area, Hubei Province, China in 2019. To assist medical staff in early detecting symptoms experienced by patients and facilitate the administration of hospital records, one of them was made an expert system that could detect this COVID-19 early with the Certainty Factor (CF) method. This expert system mimics similar symptoms experienced by COVID-19 patients and will be grouped into several patient statuses. Patients who experience serious symptoms will be grouped into Patients Under Supervision (PDP) and patients who are considered to have milder symptoms will be grouped into Insider Oversight status (ODP) while those who experience symptoms that are outside of the main symptoms will be classified into Non Suspect (NON) status. From 152 patient data inputted in this study, 114 ODP results with an average CF value of 91.38\%, 36 PDP with an average CF value of $98.25 \%$ and 2 NONs with an average CF value of $40 \%$. CF with system calculation experiments that represent patients get a CF value of 0.998848 or $99.88 \%$ to PDP. This expert system can be used to make decisions that can help medical personnel perform actions and administer better before conducting a through test in the laboratory to ensure positive or negative patients COVID-19.
\end{abstract}

Keywords: CF, COVID-19, ODP, PDP, NON, Patient

\section{PENDAHULUAN}

Corona Virus Desease atau yang sering kita kenal dengan istilah COVID-19 merupakan penyakit menular yang disebabkan oleh oleh jenis coronavirus yang baru ditemukan. Ini merupakan virus baru dan penyakit yang sebelumnya tidak dikenal sebelum terjadi wabah di Wuhan, Tiongkok, bulan Desember 2019 [1]. Wabah ini kemudian menyebar hampir keseluruh negara-negara di dunia yang mengakibatkan timbulnya kepanikan masyarakat yang khawatir dengan COVID-19 ini. Sebagai organisasi kesehatan dunia, World Health Organization (WHO) menyatakan COVID-19 ini sebagai kondisi pandemi, fokus yang harus ditekankan yaitu pada deteksi lebih cepat dan lebih awal untuk menghentikan jumlah infeksi dan untuk melaksanakan manajemen yang tepat dalam membatasi transmisi virus [2].

Indonesia merupakan salah satu negara yang beresiko tinggi terpapar COVID-19 karena banyaknya jumlah penduduk dan beragamnya budaya yang ada di masyarakat yang tersebar di seluruh wilayah Indonesia [3]. Dengan kondisi tersebut, mengakibatkan sulitnya untuk melakukan deteksi awal atau deteksi sejak dini COVID19 agar dapat melakukan upaya pencegahan sebagaimana instruksi WHO. Upaya pencegahan ini dengan membuat sistem pakar yang dapat membantu para tenaga medis melakukan deteksi dini infeksi COVID-19 dengan mengkalisifikasikan diagnosa kedalam tiga kategori yaitu Non Suspect, ODP dan PDP. Diagnosa adalah proses pemilihan diantara berbagai alternatif yang betujuan untuk memenuhi sasaran. Sistem diagnosa memiliki 4 fase yaitu, intelligence, design, chice dan implementation [4].

Dalam merancang system pakar ini menggunakan suatu metode yang disebut dengan Certainty Factor (CF) yang merupakan suatu metode untuk dapat membuktikan apakah suatu fakta yang terjadi disebut pasti atau 
JURNAL MEDIA INFORMATIKA BUDIDARMA

Volume 4, Nomor 3, Juli 2020, Page 559-566

ISSN 2614-5278 (media cetak), ISSN 2548-8368 (media online)

Available Online at https://ejurnal.stmik-budidarma.ac.id/index.php/mib

DOI 10.30865/mib.v4i3.2132

tidak pasti yang berbentuk matriks [5]. Sistem pakar ini dapat digunakan sebagai rujukan dini pendeteksi seseorang terinfeksi COVID-19 atau tidak dengan menunggu hasil laboratorium untuk memastikannya sehingga pasien bisa ditangani lebih cepat sesuai dengan protokol standar WHO.

\section{METODOLOGI PENELITIAN}

Metode yang digunakan adalah dengan cara wawancara pasien yang akan diperiksa dengan menanyakan gejala yang dialami. Setelah waancara dilakukan dan hasil wawancara diinput pada sistem, dilakukan perhitungan $\mathrm{CF}$ yaitu suatu metode untuk dapat membuktikan apakah suatu fakta yang terjadi disebut pasti atau tidak pasti yang berbentuk matriks.

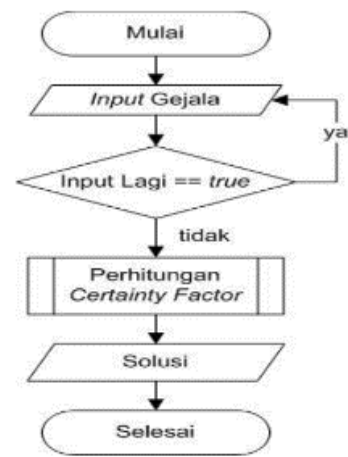

Gambar 1. Diagram Alur Penginputan Gejala

CF menggunakan suatu nilai untuk mengasumsikan derajat keyakinan seseorang pakar terhadap suatu nilai. Metode ini menggunakan perhitungan berdasarkan kemiripan yang dibagi dengan bobot yang telah ditentukan. Metode CF menunjukan suatu ukuran kepastian terhadap suatu fakta atau aturan. CF merupakan parameter klinis yang diberikan MYCIN yang digunakan untuk menunjukan besarnya suatu kepercayaan [6]. Rumus dasar CF yaitu:$$
\mathrm{CF}(\mathrm{h}, \mathrm{e})=\mathrm{MB}(\mathrm{h}, \mathrm{e})-\mathrm{MD}(\mathrm{h}, \mathrm{e})
$$
Keterangan:
$\mathrm{CF}(\mathrm{h}, \mathrm{e})$
$\mathrm{MB}(\mathrm{h}, \mathrm{e})$
$\operatorname{MD}(\mathrm{h}, \mathrm{e})$
$\mathrm{h}$
$=$ Faktor kepastian dalam hipotesis $\mathrm{h}$ yang dipengaruhi oleh evidence $\mathrm{e}$
$=$ Measure of believe merupakan ukuran kepercayan dari hipotesa $\mathrm{h}$ yang dipengaruhi oleh evidence $\mathrm{e}$
= Measure of disbelieve merupakan ukuran ketidak percayaan dari hipotesa $\mathrm{h}$ yang dipengaruhi oleh evidence e
= Hipotesa atau kesimpulan yang dihasilkan bernilai antara 0 sampai 1
= Evidence atau fakta (gejala)

e

Perhitungan berikutnya adalah perhitungan kombinasi dua atau lebih aturan dengan fakta atau gejala yang berbeda tetapi dalam hipotesa yang sama :

Aturan 1

Aturan 2

$$
\mathrm{CF}(\mathrm{h}, \mathrm{e} 1)=\mathrm{CF} 1=\mathrm{C}(\mathrm{e} 1) \mathrm{x}(\mathrm{CF} \text { aturan } 1)
$$

$$
\mathrm{CF}(\mathrm{h}, \mathrm{e} 2)=\mathrm{CF} 2=\mathrm{C}(\mathrm{e} 2) \mathrm{x}(\mathrm{CF} \text { aturan } 2)
$$

$\mathrm{CF}$ kombinasi $[\mathrm{CF} 1, \mathrm{CF} 2]=\mathrm{CF} 1+\mathrm{CF} 2(1-\mathrm{CF} 1)$

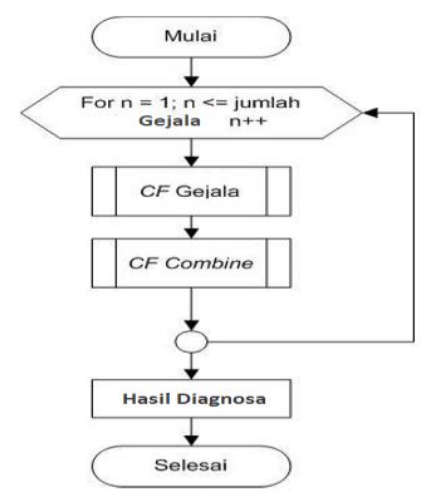

Gambar 2. Diagram Alur Perhitungan CF 


\section{HASIL DAN PEMBAHASAN}

Penelitian dilakukan dengan beberapa tahapan yang meliputi penentuan basis pengetahuan, pemodelan aturan CF, proses perhitungan sistem, dan implementasi sistem. Basis pengetahuan dilakukan untuk menentukan hipotesa dan evidence yang terjadi pada masing-masing status pasien yang dikategorikan kedalam 3 kategori yang meliputi Pasien Dalam Pengawasan (PDP), Orang Dalam Pemantauan (ODP) dan orang yang dianggap non suspect (NON). Pemodelan aturan CF yaitu proses pemodelen algoritma yang dihubungkan dari status pasien dan gejala. Contohnya pemodelan aturn CF ini yaitu jika mengalami demam maka flu. Dalam rumus yang dibuat yaitu (if demam then flu). Untuk proses perhitungan yang dilakukan yaitu proses perhitugan sistem dengan mengacu pada rumus $\mathrm{CF}$ dengan menentukan CF pakar dan CF user yang dipilih berdasarkan gejala yang dialami oleh pasien yang diperiksa. perhitungan dibuat 2 model yaitu perhitungan sistem dan perhitungan manual. Perhitungan sistem pada penelitian ini dilakukan dengan menginput data pasisn sebanyak 152 pasien. Sedangkan proses perhitungan manual hanya dilakukan kepada yang mewakili pasien. Fungsi dari peritungan manual yaitu untuk memastikan output perhitungan sistem telah berjalan dengan baik sesuai aturan dari rumus CF. Sedangkan tahap yang terakhir yaitu tahap implementasi yaitu tahap dimana implementasi dengan membuat aplikasi sistem untuk menghasilkan output atau hasil dari perhitungan CF. proses implementasi ini ditunjukan dengan desain antar muka dari aplikasi yang dibuat dimulai dari proses user atau admin login, menentukan status pasien, menentukan gejala, menentukan pengetahuan, mendiagnosa hingga hasil diagnosa yang dibuat dengan menu - menu yang dibuat didalam aplikasi.

\subsection{Basis Pengetahuan}

Basis pengetahuan ini dengan menentukan gejala penyakit yang dialami oleh pasien positif COVID-19 secara umum ada beberapa yang mempunyai spesifikasi utama seperti pada tabel berikut :

Tabel 1. Nama gejala

\begin{tabular}{cl}
\hline Kode & \multicolumn{1}{c}{ Nama Gejala } \\
\hline G01* & Pergi ke luar negeri yang terdampak COVID-19 \\
G02* & Batuk kering \\
G03* & Berusia $>50$ tahun \\
G04* & Kelelahan \\
G05* & Demam dengan suhu lebih dari 38 derajat Celsius \\
G06* & Pernah kontak langsung dengan orang yang terinfeksi COVID-19 \\
G07* & Sesak nafas \\
G08 & Hidung tersumbat \\
G09* & Tenggorokan sakit \\
G10 & Bersin-bersin \\
G11* & Sinar X pada paru-paru \\
G12* & Pernafasan cepat tak normal \\
\hline
\end{tabular}

Keterangan * :

Gejala utama penderita COVID-19

Tabel 2. Status pasien

\begin{tabular}{cl}
\hline Kode & \multicolumn{1}{c}{ Hasil } \\
\hline ODP & Orang Dalam Pemantauan (ODP) \\
PDP & Pasien Dalam Pengawasan (PDP) \\
NON & Non Suspect \\
\hline
\end{tabular}

Nama gejala akan dihubungkan dengan relasi status pasien berdasarkan fakta yang telah terjadi dilapangan dengan memperhatikan aturan $\mathrm{CF}$.

\subsection{Aturan CF}

Penerapan metode $\mathrm{CF}$ memerlukan aturan berupa variabel gejala dengan symbol $\mathrm{G}$ dan nilai bobot yang diberikan oleh pakar. Pakar memberikan bobot untuk tiap gejala 0-1. Nilai bobot pada diagnosa ditunjukan pada tabel rule. Pada tabel ini digambarkan algoritma hubungan antara hipotesa atau status pasien dengan evidence atau gejala yang dialami oleh pasien seperti pada tabel berikut :

Tabel 3. Rule

\begin{tabular}{cl}
\hline No. & \multicolumn{1}{c}{ Rule } \\
\hline 1 & IF G01 AND G02 AND G03 AND G04 AND G05 AND G06 AND G07 AND G09 AND G11 AND G12 THEN \\
& PDP \\
2 & IF G01 AND G02 AND G04 AND G05 THEN ODP \\
3 & IF G08 AND G10 THEN NON \\
\hline
\end{tabular}


JURNAL MEDIA INFORMATIKA BUDIDARMA

Volume 4, Nomor 3, Juli 2020, Page 559-566

ISSN 2614-5278 (media cetak), ISSN 2548-8368 (media online)

Available Online at https://ejurnal.stmik-budidarma.ac.id/index.php/mib

DOI 10.30865/mib.v4i3.2132

Pembobotan yang dilakukan pada sistem ini dengan langsung menginputkan nilai CF pakar antara $0-1$ dengan menghitung antara MB dan MD secara manual. Menurut penelitian yang dilakukan pada kasus yang terjadi di tiongkok mendapatkan hasil yaitu 1 dari 3 orang terinfeksi di negera tiongkok mempunyai gejala seperti yang ada pada tabel nama gejala, maka CF pakar yang diisi bisa berdasarkan penelitian tersebut atau berdadsarkan pengamatan pakar. Sedangkan pada CF user memiliki aturan jika memilih gejala tersebut maka nilai CF secara default yaitu memiliki bobot 1. Berikut adalah pembobotan yang diberikan untuk yang termasuk kriteria PDP, ODP dan non suspect:

Tabel 4. Basis pengetahuan pakar

\begin{tabular}{llllc}
\hline $\begin{array}{c}\text { Kode } \\
\text { Status }\end{array}$ & Nama Status Pasien & $\begin{array}{c}\text { Kode } \\
\text { Gejala }\end{array}$ & Nama Gejala & $\begin{array}{c}\text { Bobot } \\
\text { / CF } \\
\text { Pakar }\end{array}$ \\
\hline Non & Non Suspect & G08 & Hidung tersumbat & 0.4 \\
Non & Non Suspect & G10 & Bersin-bersin & 0.4 \\
Odp & Orang Dalam Pemantauan & G01 & Pergi ke luar negeri yang terdampak COVID-19 & 0.7 \\
Odp & Orang Dalam Pemantauan & G02 & Batuk kering & 0.6 \\
Odp & Orang Dalam Pemantauan & G05 & Demam > 38 Derajat Celcius & 0.6 \\
Odp & Orang Dalam Pemantauan & G06 & Pernah kontak dengan pasien positif COVID-19 & 0.7 \\
Pdp & Pasien Dalam Pengawasan & G01 & Pergi ke negeri yang terdampak COVID-19 & 0.7 \\
Pdp & Pasien Dalam Pengawasan & G02 & Batuk kering & 0.6 \\
Pdp & Pasien Dalam Pengawasan & G03 & Usia>50 thn & 0.6 \\
Pdp & Pasien Dalam Pengawasan & G04 & Kelelahan & 0.6 \\
Pdp & Pasien Dalam Pengawasan & G05 & Demam > 38 Derajat Celcius & 0.6 \\
Pdp & Pasien Dalam Pengawasan & G06 & Pernah kontak dengan pasien positif COVID-19 & 0.7 \\
Pdp & Pasien Dalam Pengawasan & G07 & Sesak nafas & 0.8 \\
Pdp & Pasien Dalam Pengawasan & G09 & Tenggorokan sakit & 0.6 \\
Pdp & Pasien Dalam Pengawasan & G11 & Sinar X pada paru-paru & 0.8 \\
Pdp & Pasien Dalam Pengawasan & G12 & Pernafasan cepat tak normal & 0.6 \\
\hline
\end{tabular}

Setelah dilakukan pembobotan pada masing-masing nama status dan nama gejala yang dialami, maka user dapat langsung melakukan diagnosa pada pasien dengan menggunakan aplikasi yang telah dibuat seperti berikut :

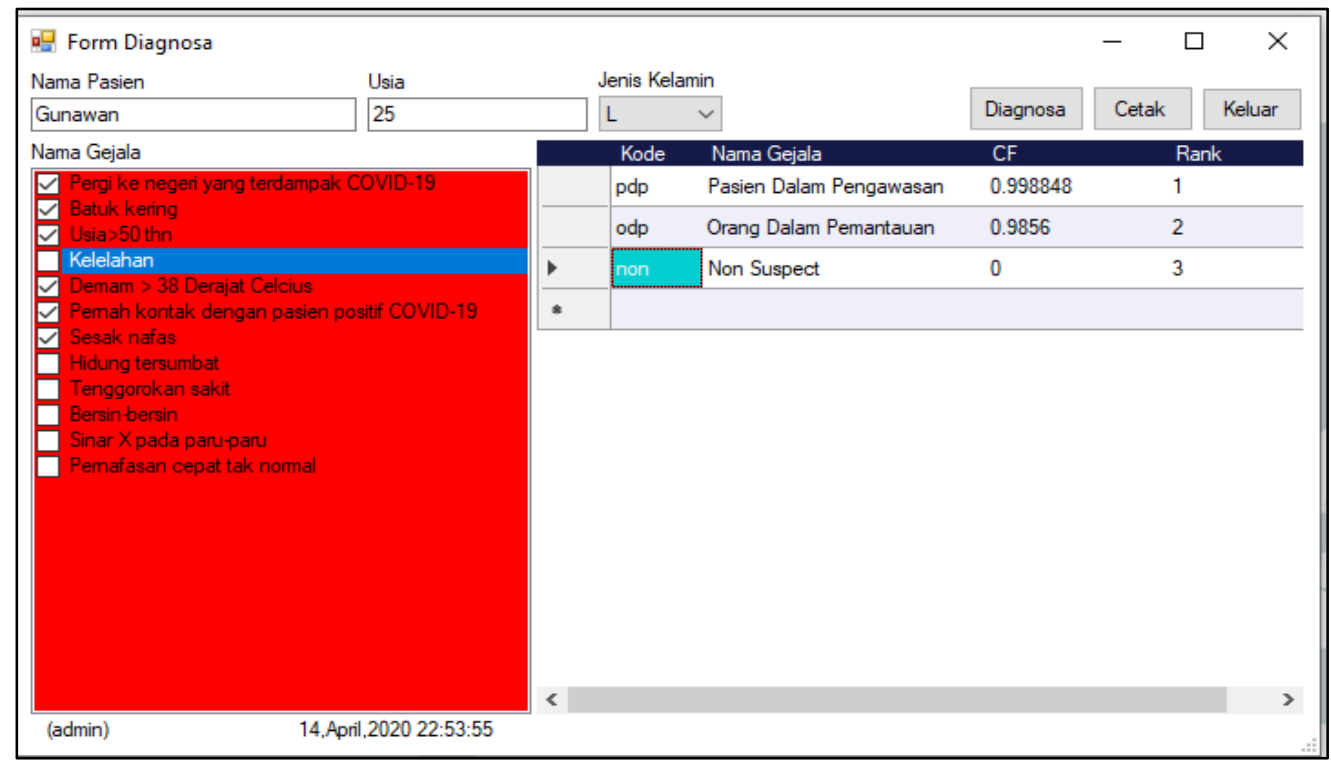

Gambar 3. Proses diagnosa pasien

Pada proses diagnosa user memilih gejala berdasarkan gejala yang dialami pasien yang diderita atau dialami sehingga ketika user klik diagnosa sistem akam mulai menghitung CF dan akan meranking nilai perhitungan yang paling besar hingga yang paling kecil. Status pasien dengan nilai CF yang paling besar akan dipilih menjadi hasil paling utama yang asuk database. Perhitungan dimulai dengan menentukan nilai aturan atau rule (1 dan 2).

Tabel 5. Perhitungan gejala dipilih

\begin{tabular}{rrrrr}
\hline \multirow{2}{*}{ Iterasi } & Nama Gejala & CF Pakar & CF User & \multicolumn{2}{c}{ CF Pakar* CF } \\
User
\end{tabular}


JURNAL MEDIA INFORMATIKA BUDIDARMA

Volume 4, Nomor 3, Juli 2020, Page 559-566

ISSN 2614-5278 (media cetak), ISSN 2548-8368 (media online)

Available Online at https://ejurnal.stmik-budidarma.ac.id/index.php/mib

DOI $10.30865 /$ mib.v4i3.2132

\begin{tabular}{rlrrr}
\hline \multirow{2}{*}{ Iterasi } & \multicolumn{1}{c}{ Nama Gejala } & CF Pakar & CF User & \multicolumn{2}{c}{ CF Pakar * CF } \\
& & 0.6 & 1 & 0.6 \\
2 & Batuk kering & 0.6 & 1 & 0.6 \\
3 & Demam > 38 derajat celcius & 0.7 & 1 & 0.7 \\
4 & Pernah kontak dengan pasien positif COVID-19 & 0.8 & 1 & 0.8 \\
5 & Sesak nafas & 0.8 & (1) \\
\hline
\end{tabular}

\subsection{Perhitungan Sistem}

Proses pengitungan sistem menggunakan rumus perhitungan (3) yaitu persamaan CF kombinasi karena terdapat lebih dari 1 gejala yang diinputkan oleh user. Setelah kita mendapatka hasil dari perhitungan $\mathrm{CF}$ pakar dan $\mathrm{CF}$ user sebelumnya, maka selanjutnya perhitungan dengan menghasilkan CF yang akan digunakan untuk menghitung CF kombinasinya.

Tabel 6. Hasil perhitungan manual pasien gunawan sistem ranking 1

\begin{tabular}{|c|c|}
\hline \multicolumn{2}{|r|}{ Kemungkinan 1 menjadi PDP } \\
\hline Iterasi & $C F 1+(C F 2 *(1-C F 1)$ \\
\hline 1 & $0.7+(0.6 *(1-0.7))=0.88$ \\
\hline 2 & $0.88+(0.6 *(1-0.88))=0.952$ \\
\hline 3 & $0.952+(0.6 *(1-0.952))=0.9808$ \\
\hline 4 & $0.9808+(0.7 *(1-0.9808))=0.99424$ \\
\hline 5 & $0.99424+(0.8 *(1-0.99424))=0.998848$ \\
\hline Hasil & $0.998848 * 100=99.88 \%$ \\
\hline
\end{tabular}

Tabel 7. Hasil perhitungan manual pasien gunawan sistem ranking 2

\begin{tabular}{|c|c|}
\hline \multicolumn{2}{|r|}{ Kemungkinan 2 menjadi ODP } \\
\hline Iterasi & $C F 1+(C F 2 *(1-C F 1)$ \\
\hline 1 & $0.7+(0.6 *(1-0.7))=0.88$ \\
\hline 2 & $0.88+(0.6 *(1-0.88))=0.952$ \\
\hline 3 & $0.952+(0.7 *(1-0.952))=0.9856$ \\
\hline Hasil & $0.9856 * 100=98.56 \%$ \\
\hline
\end{tabular}

Dari hasil perhitungan tersebut dapat dilihat skor paling tinggi yang didapat adalah kemungkinan pertama pasien menjadi status PDP dan akan diberikan solusi oleh user sebelum benar-benar dinyatakan positif COVID-19 dengan menjalani tes laboratorium untuk memastikan. Kemungkinan kedua yaitu pasien menjadi ODP.

Perhitungan pada penelitian ini dilakukan pada 152 pasien tetapi yang dilakukan penghitungan manual adalah data yang mewakili pasien. Dari perhitungan 152 pasien yang diinput menghasilkan output pada sebagai berikut:

Tabel 8. Hasil perhitungan 152 pasien

\begin{tabular}{cccc}
\hline $\begin{array}{c}\text { Kode } \\
\text { Status }\end{array}$ & Nama Status & Rata-rata CF \% & Total \\
\hline Non & Non Suspect & 40.00 & 2 \\
Odp & Orang Dalam Pemantauan & 91.38 & 114 \\
Pdp & Pasien Dalam Pengawasan & 98.25 & 36 \\
& Grand Total & & $\mathbf{1 5 2}$ \\
\hline
\end{tabular}

\subsection{Implementasi Desain Antar Muka}

Menu login digunakan untuk masuk kedalam sistem menggunakan autentifikasi user dan password yang telah terdaftar pada database user.

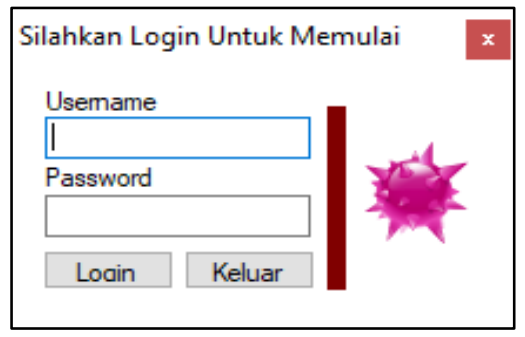

Gambar 4. Antar muka login 
JURNAL MEDIA INFORMATIKA BUDIDARMA

Volume 4, Nomor 3, Juli 2020, Page 559-566

ISSN 2614-5278 (media cetak), ISSN 2548-8368 (media online)

Available Online at https://ejurnal.stmik-budidarma.ac.id/index.php/mib

DOI 10.30865/mib.v4i3.2132

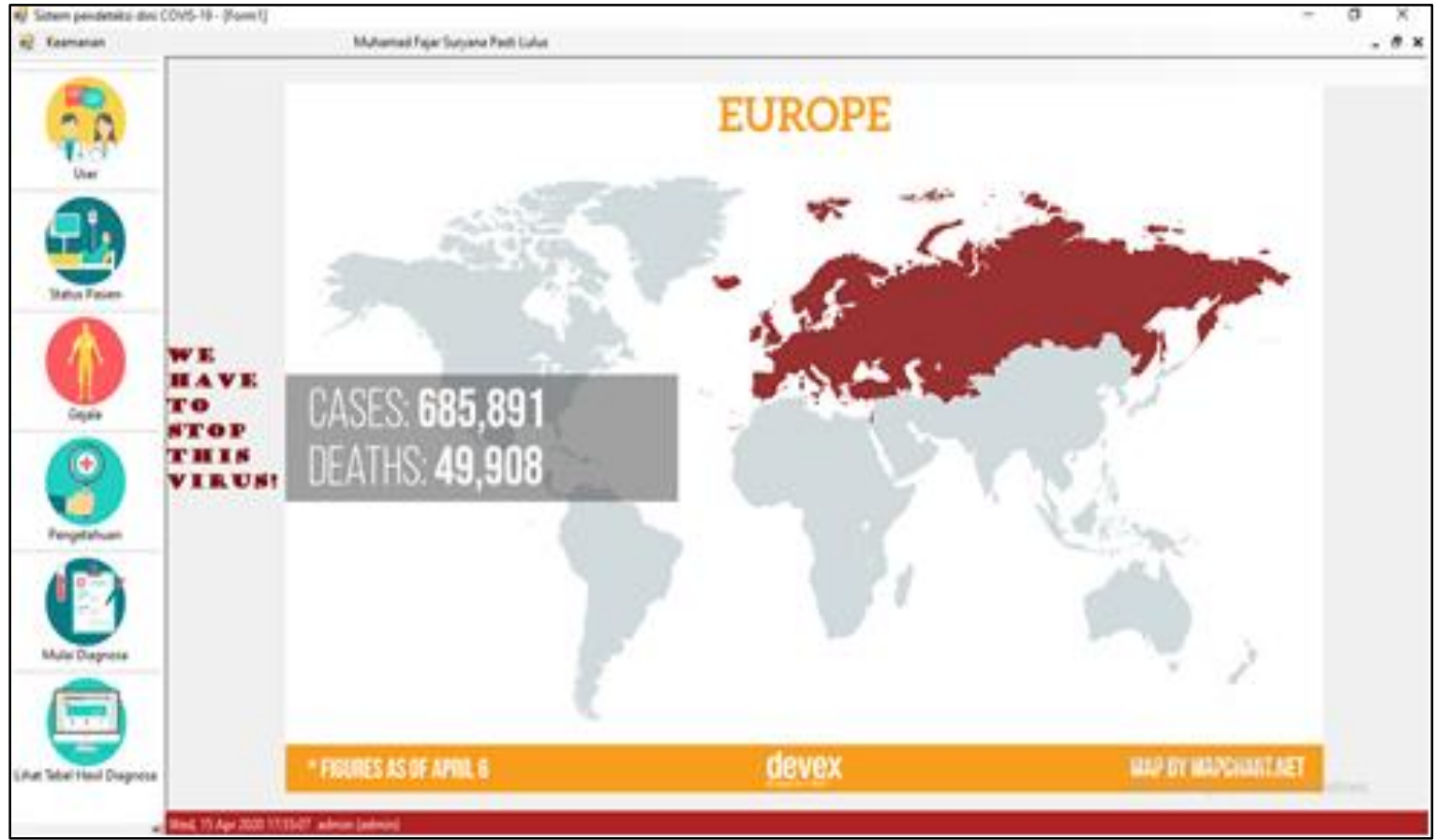

Gambar 5. Antar muka menu utama

Menu utama pada admin dapat mengakses seluruh menu yang ada pada aplikasi. Tetapi pada menu utama dengan hak akses user, menu user tidak dapat diakses.

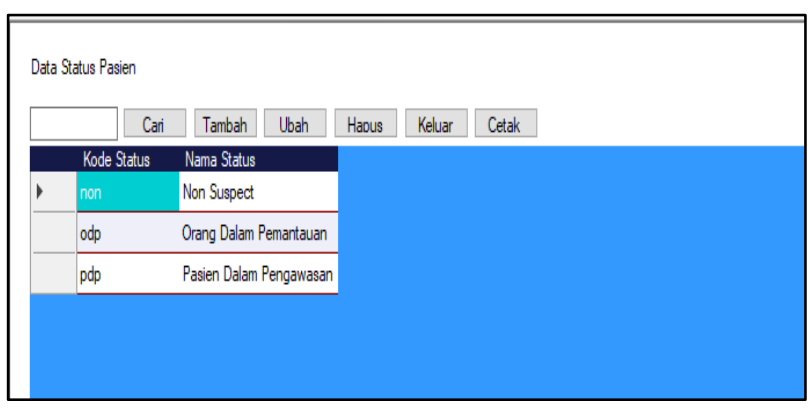

Gambar 6. Antar muka status pasien

Menu status pasien digunakan untuk menambahkan, mengubah atau menghapus data status pasien yang didalamnya terdapat solusi pada masing-masing status diagnosa.

\begin{tabular}{|c|c|c|c|c|c|}
\hline \multicolumn{6}{|c|}{ Data Gejala } \\
\hline & Cari & Tambah & Haous & Keluar & Cetak \\
\hline & Kode_gejala & \multicolumn{3}{|c|}{ Nama_gejala } & \\
\hline \multirow[t]{12}{*}{ 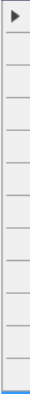 } & G01 & \multicolumn{3}{|c|}{ Pergi ke negeri yang terdampak COVID-19 } & \\
\hline & G02 & \multicolumn{3}{|l|}{ Batuk kering } & \\
\hline & G03 & \multicolumn{3}{|l|}{ Usia $>50$ thn } & \\
\hline & G04 & \multicolumn{3}{|l|}{ Kelelahan } & \\
\hline & G05 & \multicolumn{3}{|c|}{ Demam > 38 Derajat Celcius } & \\
\hline & G06 & \multicolumn{3}{|c|}{ Pemah kontak dengan pasien positif COVID-19 } & \\
\hline & G07 & \multicolumn{3}{|l|}{ Sesak nafas } & \\
\hline & G08 & \multicolumn{3}{|l|}{ Hidung tersumbat } & \\
\hline & G09 & \multicolumn{3}{|l|}{ Tenggorokan sakit } & \\
\hline & G10 & \multicolumn{3}{|l|}{ Bersin bersin } & \\
\hline & G11 & \multicolumn{3}{|l|}{ Sinar $X$ pada paru-paru } & \\
\hline & G12 & \multicolumn{3}{|c|}{ Pemafasan cepat tak normal } & \\
\hline
\end{tabular}

Gambar 7. Antar muka gejala

Menu gejala digunakan untuk menambah, mengubah atau menghapus data gejala. 
ISSN 2614-5278 (media cetak), ISSN 2548-8368 (media online)

Available Online at https://ejurnal.stmik-budidarma.ac.id/index.php/mib

DOI $10.30865 /$ mib.v4i3.2132

\begin{tabular}{|c|c|c|c|c|c|c|c|c|}
\hline \multicolumn{9}{|c|}{ Data Pengetahuan } \\
\hline & & Cani & Tambah & Ubah & Haous & Keluar & Cetak & \\
\hline & \multicolumn{2}{|c|}{$\begin{array}{l}\text { Kode } \\
\text { Diagnosa }\end{array}$} & Nama Diagn & & $\begin{array}{l}\text { Kode } \\
\text { Gejala }\end{array}$ & \multicolumn{2}{|c|}{ Nama Gejala } & $\begin{array}{l}\text { Bobot/CF } \\
\text { Pakar }\end{array}$ \\
\hline \multirow[t]{16}{*}{ 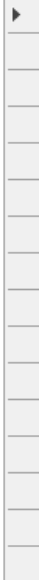 } & \multicolumn{2}{|l|}{ non } & \multicolumn{2}{|c|}{ Non Suspect } & G08 & \multicolumn{2}{|c|}{ Hidung tersumbat } & 0.4 \\
\hline & \multicolumn{2}{|l|}{ non } & \multicolumn{2}{|l|}{ Non Suspect } & G10 & \multicolumn{2}{|c|}{ Bersin bersin } & 0.4 \\
\hline & \multicolumn{2}{|l|}{ odp } & \multicolumn{2}{|c|}{ Orang Dalam Pemantauan } & G01 & \multicolumn{2}{|c|}{ Pergi ke negen yang terdampak COVID-19 } & 0.7 \\
\hline & \multicolumn{2}{|l|}{ odp } & \multicolumn{2}{|c|}{ Orang Dalam Pemantauan } & G02 & \multicolumn{2}{|c|}{ Batuk kering } & 0.6 \\
\hline & \multicolumn{2}{|l|}{ odp } & \multicolumn{2}{|c|}{ Orang Dalam Pemantauan } & G05 & \multicolumn{2}{|c|}{ Demam > 38 Derajat Celcius } & 0.6 \\
\hline & \multicolumn{2}{|l|}{ odp } & \multicolumn{2}{|c|}{ Orang Dalam Pemantauan } & G06 & \multicolumn{2}{|c|}{ Pemah kontak dengan pasien positf COVID-19 } & 0.7 \\
\hline & \multicolumn{2}{|l|}{ pdp } & \multicolumn{2}{|c|}{ Pasien Dalam Pengawasan } & G01 & \multicolumn{2}{|c|}{ Pergi ke negeri yang terdampak COVID-19 } & 0.7 \\
\hline & \multicolumn{2}{|l|}{ pdp } & \multicolumn{2}{|c|}{ Pasien Dalam Pengawasan } & G02 & \multicolumn{2}{|c|}{ Batuk kering } & 0.6 \\
\hline & \multicolumn{2}{|l|}{ pdp } & \multicolumn{2}{|c|}{ Pasien Dalam Pengawasan } & G03 & \multicolumn{2}{|c|}{ Usia $>50$ thn } & 0.6 \\
\hline & \multicolumn{2}{|l|}{ pdp } & \multicolumn{2}{|c|}{ Pasien Dalam Pengawasan } & G04 & \multicolumn{2}{|c|}{ Kelelahan } & 0.6 \\
\hline & \multicolumn{2}{|l|}{ pdp } & Pasien Dalan & Pengawasan & G05 & & am > 38 Derajat Celcius & 0.6 \\
\hline & pdp & & Pasien Dalan & Pengawasan & G06 & & ah kontak dengan pasien positif COVID-19 & 0.7 \\
\hline & pdp & & Pasien Dalar & Pengawasan & G07 & & k nafas & 0.8 \\
\hline & pdp & & Pasien Dalan & Pengawasan & G09 & & gorokan sakit & 0.6 \\
\hline & pdp & & Pasien Dalan & Pengawasan & G11 & & X pada paru-paru & 0.8 \\
\hline & pdp & & Pasien Dalan & Pengawasan & G12 & & afasan cepat tak nomal & 0.6 \\
\hline
\end{tabular}

Gambar 8. Antar muka pengetahuan

Menu pengetahuan digunakan untuk menentukan bobot dan relasi antara status diagnosa pasien dan gejala.

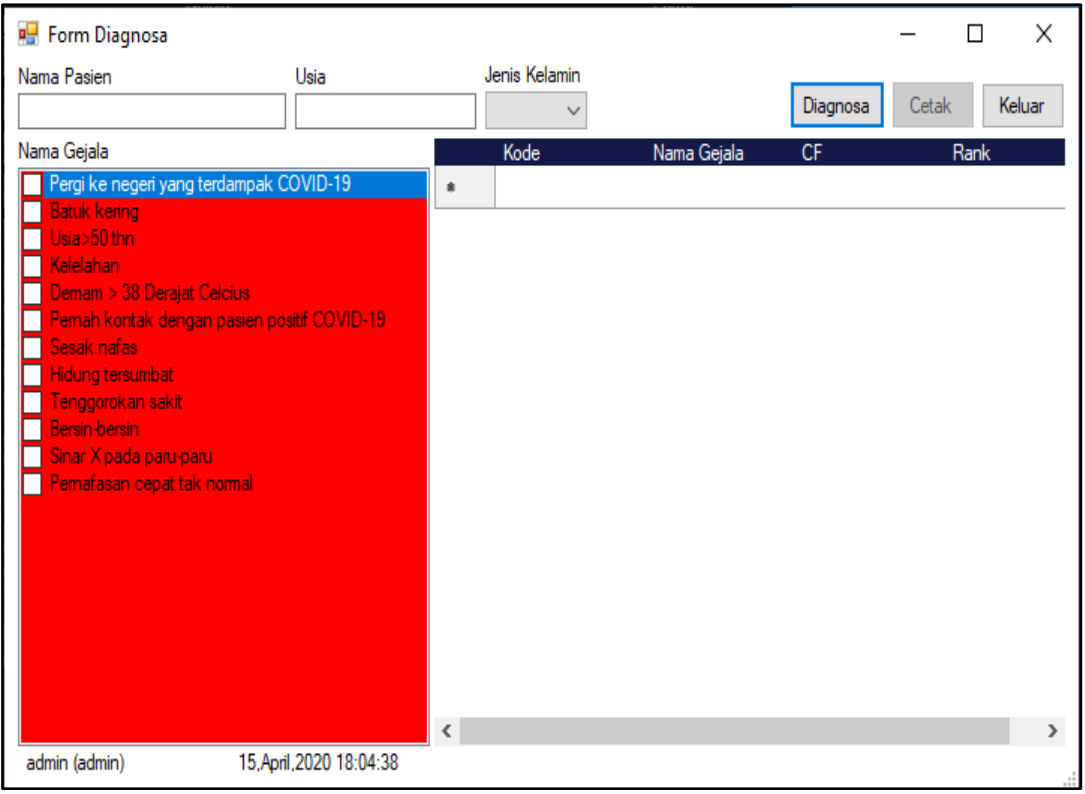

Gambar 9. Antar muka diagnosa

Menu diagnosa digunakan untuk mendiagnosa pasien dan yang memunculkan tabel gejala yang dialami oleh pasien. Setelah data gejala dipilih dan data pasien telah dilengkapi, proses diagnose akan dimulain dengan perhitungan $\mathrm{CF}$. hasil diagnosa akan dimunculkan dengan mengurutkan nilai $\mathrm{CF}$ dari yang terbesar hingga yang terkecil.

\section{KESIMPULAN}

Berikut ini kesimpulan yang dapat diambil dari Perancangan Aplikasi dari penelitian yang telah dilakukan dapat disimpulkan bahwa :

1. Menghasilkan aplikasi sistem pakar untuk mendiagnosa dini COVID-19 dengan mengelompokan status pasien seperti : PDP, ODP dam Non Suspect yang akan diperdalam dengan hasil uji lab untuk memastikan pasien dinyatakan positif atau negatif terinfeksi COVID-19.

2. Dari perhitungan nilai CF 152 pasien yang diinput pada penelitian ini menghasilkan 114 ODP, 36 PDP dan 2 NON dengan masing-masing memiliki rata-rata nilai CF 98,25\%, 91,38\% dan 40\%. dan sudah sesuai hasil yang didapatkan berdasarkan gejala yang dialami oleh pasien. 
JURNAL MEDIA INFORMATIKA BUDIDARMA

Volume 4, Nomor 3, Juli 2020, Page 559-566

ISSN 2614-5278 (media cetak), ISSN 2548-8368 (media online)

Available Online at https://ejurnal.stmik-budidarma.ac.id/index.php/mib

DOI 10.30865/mib.v4i3.2132

3. Sistem aplikasi pakar ini dapat dipergunakan untuk membantu pengambilan keputusan dan pengadministrasi data pasien sebagai bentuk penanganan dan pencegahan terhadap penularan COVID-19.

4. Sistem ini dapat membantu mendiagnosa dini sebagai alternative pengganti seorang pakar dan memberikan informasi yang sama layaknya seorang pakar.

\section{UCAPAN TERIMAKASIH}

Terimakasih diucapkan kepada Allah SWT. dan kepada pihak yang telah membantu penelitian ini sehingga penelitian bisa dilakukan dengan lancar terutama pihak tenaga medis yang sedang berjuang membantu untuk dapat menjadi garda terdepan penanggulangan COVID-19.

\section{REFERENCES}

[1] World Health Organization.(2020, April 17) Q\&A on coronaviruses (COVID-19) [online].Available: https://www.who.int/news-room/q-a-detail/q-a-coronaviruses

[2] Agus Rizal Ardy Hariandi Hamdi, “ A Concern for COVID-19 Pandemic”, Social Resposibility of Medical Journal, vol. 2, no. 1, Maret 2020.

[3] Lisbet Sihombing, "Penyebaran COVID-19 dan Respon Internasional", Pusat Penelitian Badan Keahlian DPR RI, Vol. XII, No. 5/I/Puslit/Maret/2020, Maret 2020.

[4] Yulianti Paula Bria and Engelbertus Agung S. Takung, "Pengembangan Sistem Pakar Diagnosis Penyakit Tuberculosis dan Demam Berdarah Berbasis Web Menggunakan Metode Certainty Factor", SENTIKA, 2015.

[5] Elizabeth Paskahlia Gunawan and Retantyo Wardoyo, "An Expert System Using Certainty Factor For Determining Insomnia Acupoint”, Indonesian Journal of Computing and Cybernetics System, vol. 2, no. 12, Juli 2018.

[6] Y Findawati dan A I Afrina, "Expert System Diagnosa Disease Dermatitis Using Web Based Certainty Factor", International Conference on Engineering and Applied Technology, no.10.1088/1757-899X/403/1/012068, 2018.

[7] CDC COVID-19 Response Team, "Severe Outcomes Among Patients with Coronavirus Disease 2019 (COVID-19)", Centers for Diseases Control and Prevention, Vol. 69, Maret 2020.

[8] Merlina, Nita M.Kom., dan Rahmat Hidayat S.Kom., Perancangan Sistem Pakar. Ghalia Indonesia, 2012.

[9] Miles, Rob, C\# Programming Yellow Book. Cheese Edition, 2016.

[10] Paul Weiss and David R Murdoch, “COVID-19: Towards Controlling of a Pandemic”, The Lancet, Vol. 395, Maret 2020 P1015-P1018.

[11] Shaila Rahman and Tamanna Bahar, “COVID-19:The New Threat”, Int J Infect, Januari 2020.

[12] Yuliana, "Corona Virus Diseases (COVID-19”,Wellness and Health Magazine, Vol. 2, No. 1, Februari 2020. 